\title{
Design and performance investigation of a thermal back-up system for hybrid drying
}

\author{
T. A. Yassen, H. H. Al-Kayiem \& K. Habib \\ Universiti Teknologi PETRONAS, Perak, Malaysia
}

\begin{abstract}
A major setback in the solar drying technique is the lack of solar energy during cloudy and rainy days as well as during the night. Thus, the hybrid solar thermal drying techniques are feasible as a practical solution. This paper presents the design, fabrication, and test of a thermal back-up unit comprising a burner and a gas to gas heat exchanger. The test was accomplished with a feeding rate of 0.426 and $0.271 \mathrm{~kg} / \mathrm{hr}$ of coal. Results have shown that the temperature of the supplied hot air at the feeding rate of $0.426 \mathrm{~kg} / \mathrm{hr}$, was higher than the ambient temperature by $60^{\circ} \mathrm{C}$ maximum, while it is $40^{\circ} \mathrm{C}$ maximum with feeding rate of $0.271 \mathrm{~kg} / \mathrm{hr}$. The decrease in the feeding rate of coal leads to a stable hot air temperature for a long time of burning. The present thermal back-up unit is feasible for providing hot air suitable for the drying of any type of agriculture, forest, and food products. The advantage of using such a system is important in the rural areas, where it operates and performs hybrid drying, free of electricity. Keywords: hybrid drying, thermal back up, solar drying, food products, agriculture products.
\end{abstract}

\section{Introduction}

The solar drying process is suffering from the lack of sunlight interruption during cloudy and rainy days as well as throughout the night. Integration of the solar dryer with another resource of energy is the most appropriate practical solution to get continuity in drying process.

Prasad and Vijay [1] fabricated, and studied natural convection solar dryer coupled with a biomass stove. Brick walls of $(1.45 \times 1.17 \times 0.9) \mathrm{m}^{3}$ surrounded the biomass stove. A burner with a holed tray was provided inside the stove. A $7.5 \mathrm{~cm}$ diameter and $60 \mathrm{~cm}$ long chimney located at one side of the stove to 
allow the leaving of flue gases. In order to elongate the flow way of exhaust gases and maximize the transfer of heat to the stove walls, three metal baffle plates were inserted. The brick room has 13 rectangular slots with dimension of $0.018 \mathrm{~m}^{2}$ for fresh air access and one biomass feeding slot with dimension of $0.11 \mathrm{~m}^{2}$. The quantity of $6 \mathrm{~kg}$ charcoal is burned. The temperature measured at the bottom of the tray $59.5^{\circ} \mathrm{C}$.

An indirect natural convection solar dryer integrated with biomass-backup heaters has been designed, constructed and evaluated by Madhlopa and Ngwalo [2]. The parts of the biomass burner were composed of drum, rectangular duct and flue gas chimney. The burner was designed with drum length of $0.89 \mathrm{~m}$ and $0.58 \mathrm{~m}$ diameter. The flue gas chimney height was $2.12 \mathrm{~m}$ and diameter $0.12 \mathrm{~m}$. Wood shaving was used as the fuel in the burner. The rate of fuel feeding was 8 $\mathrm{kg}$ per night. The maximum temperature recorded inside the dryer was in the range of 41 to $56^{\circ} \mathrm{C}$.

Tarigan and Tekasakul [3] studied experimentally a mixed-mode natural convection solar collector with biomass burner and heat storage back-up heater. The construction of the biomass burner consisted of a concrete wall surrounded by a thermal storage area that was built using bricks. The chimney was affixed to the upper edge of the stove in such a way that heat from the smoke could heat up the internal wall which would in turn lead to the tray being heated. Shaving wood of $50 \mathrm{~kg}$ was used through night. The temperature measured inside the drying chamber was $65^{\circ} \mathrm{C}$.

Thanaraj et al. [4] designed and developed a solar hybrid copra drying technique suitable for small holders. Three components; solar collector, furnace and heat exchanger were evaluated separately. The furnace consisted of a cylindrical shape heat exchanger and baffles to maximize the heat transfer. The wall was made from bricks, clay and cement. The average drying chamber temperatures at the husk feeding rates of $3 \mathrm{~kg} / \mathrm{h}, 5 \mathrm{~kg} / \mathrm{h}$, and $10 \mathrm{~kg} / \mathrm{h}$ were $43^{\circ} \mathrm{C}$, $53^{\circ} \mathrm{C}$, and $62^{\circ} \mathrm{C}$ and the furnace efficiencies were $43 \%, 48 \%, 70 \%$, respectively. The furnace efficiency increased with increasing husk feeding rate.

Bena and Fuller [5] studied a hybrid drying system. The system consisted of a simple biomass burner combined with a direct type natural convection solar dryer to present a different type of technology for the drying process. The biomass burner, designed mainly to be used with wood as the main fuel for burning, was built from a $0.2 \mathrm{~m}$ drum positioned on its side. Approximately, $9 \mathrm{~kg}$ of wood was burned each night, just enough to keep the temperature inside the dryer under $65^{\circ} \mathrm{C}$.

Yunus et al. [9] reported a design procedure of a thermal back-up system which was flexible to deliver hot flue to dry solid waste or to provide warm air to dry food and fish. The system constructed from biomass burner and gas to gas heat exchanger topping the burner. The design was accomplished to dry $2.5 \mathrm{~kg}$ of palm fiber (EFB). Mathematical model was developed to evaluate the dimensions of the heat exchanger. Results illustrated that heat exchanger of 0.4 $\mathrm{m}$ height and $0.4 \mathrm{~m}$ diameter is enough to produce the required flow rate and temperature of drying air. 
Al-Kayiem and Yunus [10] studied experimentally a combination of mixed mode hybrid dryer using solar as main heat input and biomass burner as auxiliary source to dry EFB. Series of experimental measurements were carried out at four different drying modes namely, open sun, mixed solar, thermal back up, and hybrid modes to dry $2.5 \mathrm{~kg}$ of EFB. The results indicated that the solar drying mode required around 50 hours to dry the EFB while it required 65 hours under open sun drying mode. By the hybrid mode, the drying time was considerably reduced to 28 hours. The application of solar dryer with biomass burner is practical to be applied for massive production of solid fuels from EFB.

The aim of this paper is to present a design, fabrication and test results of TBU integrated with solar-thermal dryer. The system was designed to meet a pre-design temperature inside the drying chamber around $65^{\circ} \mathrm{C}$. The TBU was intended to exhaust the hot air directly in the drying chamber (as shown in figure 1).

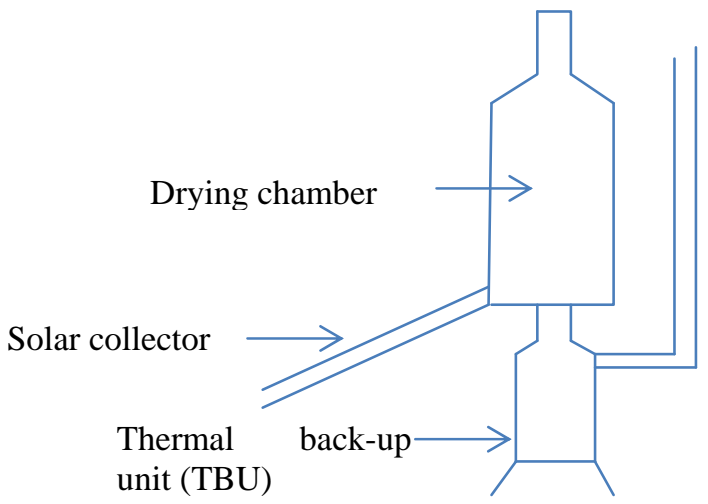

Figure 1: $\quad$ Schematic diagram of hybrid drying system.

\section{Conceptual design}

The constructed TBU was comprised of two parts. The lower part is the burner which is cylindrical shape to burn the fuel and produces the flue gases, and the upper part is the gas to gas heat exchanger. The flue gas enters into the inner concentric annulus and the air from the ambient is enters into the external annulus. To enhance the heat transfer between the flue gas and the air, eight fins were added to the external wall surface of the gas to gas heat exchanger in the air side. Figure 2 illustrates the shape of the TBU. The combustion fuel was charcoal.

\section{Mathematical modeling}

The TBU was designed to provide the heat required by the air to dry $5 \mathrm{~kg}$ of fish in the drying chamber. 


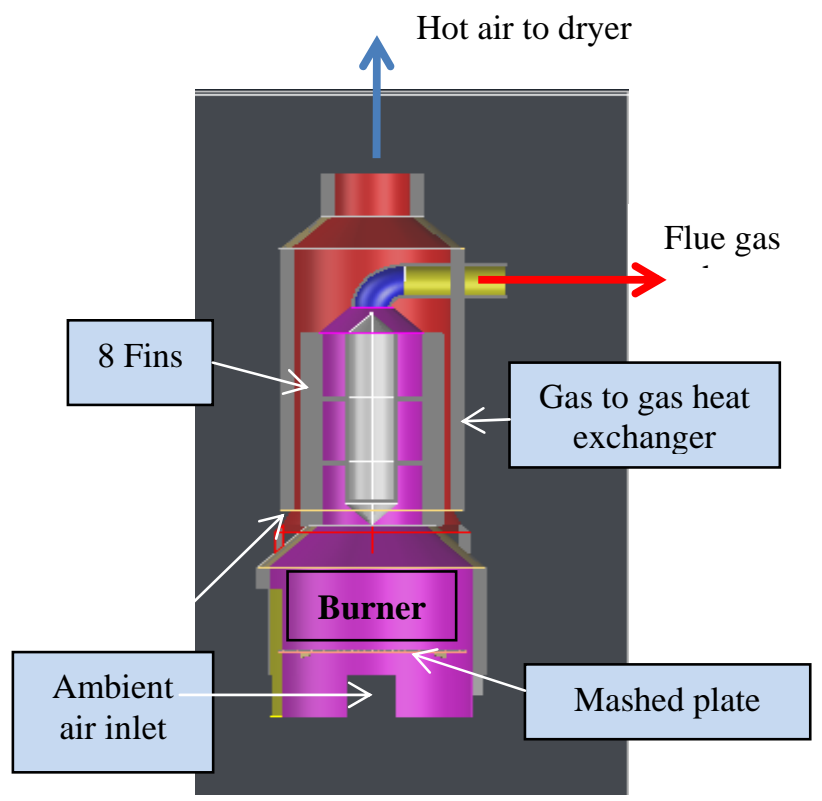

Figure 2: $\quad 3-\mathrm{D}$ sectional view of the thermal back-up unit (TBU).

The quantity of moisture to be removed, $m_{w}(\mathrm{~kg})$ depends on the material and can be found from the following relationship (Ayensu [6]):

$$
\mathrm{m}_{\mathrm{w}}=\frac{\mathrm{m}_{1}\left(\mathrm{M}_{1}-\mathrm{M}_{2}\right)}{\left(100-\mathrm{M}_{2}\right)}
$$

The quantity of heat required for drying, $Q_{d}(\mathrm{~W})$ to evaporate the water from the material is

where

$$
Q_{d}=\frac{\left(m_{\left.w^{*} h_{f g}\right)}\right.}{t}
$$

$h_{f g}(\mathrm{~kJ} / \mathrm{kg})$ is latent heat of evaporation, $m_{1}(\mathrm{~kg})$, is the initial total crop mass;

$\mathrm{M}_{1}(\mathrm{~kg})$, the initial moisture fraction on wet basis;

$\mathrm{M}_{2}(\mathrm{~kg})$, the final moisture fraction on wet basis and $\mathrm{t}(\mathrm{s})$ drying time.

Assuming the heat required to drying is equal the heat gained from TBU and equal to the heat transferred between the flue gas and the wall of heat exchanger as well as equal the heat transfer between wall and the air.

$$
Q_{d}=Q_{T B U}=Q_{1}=Q_{2}
$$

where

$\mathrm{Q}_{\mathrm{TBU}}$ : is the heat gained from $\mathrm{TBU}$, and $\mathrm{q}_{1}$ and $\mathrm{q}_{2}$ as below: 


$$
\begin{array}{r}
Q_{1}=\pi d L h_{f}\left(T_{f m}-T_{w i}\right) \\
Q_{2}=\pi d L h_{a}\left(T_{w o}-T_{a m}\right)
\end{array}
$$

$\mathrm{Q}_{1}$ : heat transfer between flue gas and the inner surface of heat exchanger. A: surface area

$\mathrm{Q}_{2}$ : heat transfer between outer surface of heat exchanger and air.

Where;

$T_{f m}$ : mean flue gas temperature,

$T_{w i}$ : inside wall temperature of heat exchanger,

$T_{\text {wo }}$ : outside wall temperature of heat exchanger,

$T_{a m}$ : mean inlet and outlet air temperature.

The outlet temperature of flue gas from heat exchanger is evaluated from:

$$
\begin{gathered}
T_{f o}=T_{f i}-\frac{Q_{d}}{\dot{m}_{f} C p} \\
T_{f m}=\frac{T_{f i}+T_{f o}}{2}
\end{gathered}
$$

where

$T_{f i}$ : the temperature of flue gas enter to heat exchanger, $m_{f}$ : mass flow rate of flue gas.

The convective heat transfer coefficient between flue gas and the inside wall of heat exchanger is:

where

$$
h_{f}=\frac{N u k_{f}}{d_{h f}}
$$

$d_{h f}$ : hydraulic diameter of concentric annulus of flue gas side $(0.1 \mathrm{~m})$, $k_{f}\left(\mathrm{~W} / \mathrm{m} .{ }^{\circ} \mathrm{C}\right)$ : conductivity of flue gas.

Assuming free convection between flue gas and wall then the convective heat transfer coefficient between vertical wall or cylinder to flue gas (McAdams [8]),

$$
\begin{gathered}
N u=0.59\left(R a^{0.25}\right) \\
h_{f}=0.59 *\left(\frac{g \beta d_{h f}^{3}\left(T_{f m}-T_{w i}\right)}{v^{2}} * P r\right)^{0.25} * \frac{K_{f}}{d_{h f}}
\end{gathered}
$$

where $\operatorname{Pr}_{f}$ : Prantal number of flue gas.

From eqn. (4), the temperature of the inside wall of heat exchanger is calculated as:

$$
T_{w i}=T_{f m}-\frac{Q_{d}}{\pi d L h_{f}}
$$

where $d=0.2 \mathrm{~m}$ is the diameter of cylinder separate the air from flue gas. By substitute eqn. (10) in eqn. (11) then: 


$$
L=\frac{Q_{d} d_{h f}}{0.59 \pi d k_{f}\left(T_{f m}-T_{w i}\right)\left(\frac{g \beta d_{h f}{ }^{3}\left(T_{f m}-T_{w i}\right) p r}{v^{2}}\right)^{0.25}}
$$

The convective heat transfer coefficient between outer vertical wall of the cylinder to air is in the air passage [8]

$$
\begin{gathered}
N u=0.59\left(R a^{0.25}\right) \\
h_{a}=0.59\left(\frac{g \beta d_{h a}^{3}\left(T_{w o}-T_{a m}\right)}{v^{2}} \operatorname{Pr}\right)^{0.25} \frac{K_{a}}{d_{h a}}
\end{gathered}
$$

where $d_{h a}$ : hydraulic diameter of annulus of air side $(0.1 \mathrm{~m})$.

To calculate $T_{a m}$, eqn. (14) was substituted in eqn. (5). Using the subroutine written on the MATLab program, the length was calculated. The parameters input to the MATLab program are shown in table 1.

Using trial and error in eq. (12), the predicted result of the length representing the height of the exchanger was $0.359 \mathrm{~m}$. The calculated length was multiplied by factor of safety 1.25 to compensate for the losses from the heat exchanger to ambient. Thus the final length of heat exchanger was equal to $0.45 \mathrm{~m}$.

\section{Results of TBU tests and discussion}

The TBU, as shown in figure 3, was tested. A set of measuring instrumentations was attached to the TBU and connected to a data acquisition system. Thermocouples type $\mathrm{K}$ (chromal - alumal) that measure temperature in the range -50 to $1000^{\circ} \mathrm{C}$ were calibrated before the experimental tests. They were found to be within $\pm 0.1^{\circ} \mathrm{C}$ as maximum in the calibration range, $0^{\circ} \mathrm{C}$ to $100^{\circ} \mathrm{C}$ was. Thermocouple wires were connected to data logger type GL820-UM-851 to

Table 1: $\quad$ Initial design parameters.

\begin{tabular}{ccc}
\hline No. & Parameter & Value \\
\hline 1 & Initial mass of fish $\left(\mathrm{m}_{1}\right)$ & $5 \mathrm{~kg}$ \\
2 & Initial moisture content of fish $\left(\mathrm{M}_{1}\right)$ & $75 \%$ \\
3 & Final moisture content $\left(\mathrm{M}_{2}\right)$ & $15 \%$ \\
4 & Inlet air temperature $\left(\mathrm{T}_{\mathrm{a}}\right)$ & $30^{\circ} \mathrm{C}$ \\
5 & Outlet hot air temperature $\left(\mathrm{T}_{\mathrm{ao}}\right)$ & $80^{\circ} \mathrm{C}$ \\
6 & Inlet flue gas temperature $\left(\mathrm{T}_{\mathrm{fi}}\right)$ previous experiment & $190^{\circ} \mathrm{C}$ \\
7 & Mass flow rate of flue gas from previous experiment $\left(\mathrm{m}_{\mathrm{f}}\right)$ & $0.0044 \mathrm{~kg} / \mathrm{s}$ \\
8 & Flue gas specific heat $(\mathrm{Cp})$ & $1097 \mathrm{~J} / \mathrm{kg} . \mathrm{K}$ \\
9 & Thermal conductivity of flue gas $\left(\mathrm{k}_{\mathrm{f}}\right)$ & $0.037 \mathrm{~W} / \mathrm{m} . \mathrm{K}$ \\
10 & Kinematic viscosity of flue gas $\left(v_{\mathrm{f}}\right)$ & $32.8^{*} 10^{-6} \mathrm{~m} / \mathrm{s}$ \\
11 & Kinematic viscosity of flue gas $(\mathrm{va})$ & $18.5^{*} 10^{-6} \mathrm{~m}{ }^{2} / \mathrm{s}$ \\
12 & Thermal conductivity of air $\left(\mathrm{k}_{\mathrm{a}}\right)$ & $0.028 \mathrm{~W} / \mathrm{m} . \mathrm{K}$ \\
13 & Prandtl number for air and flue gas & 0.7 \\
\hline
\end{tabular}




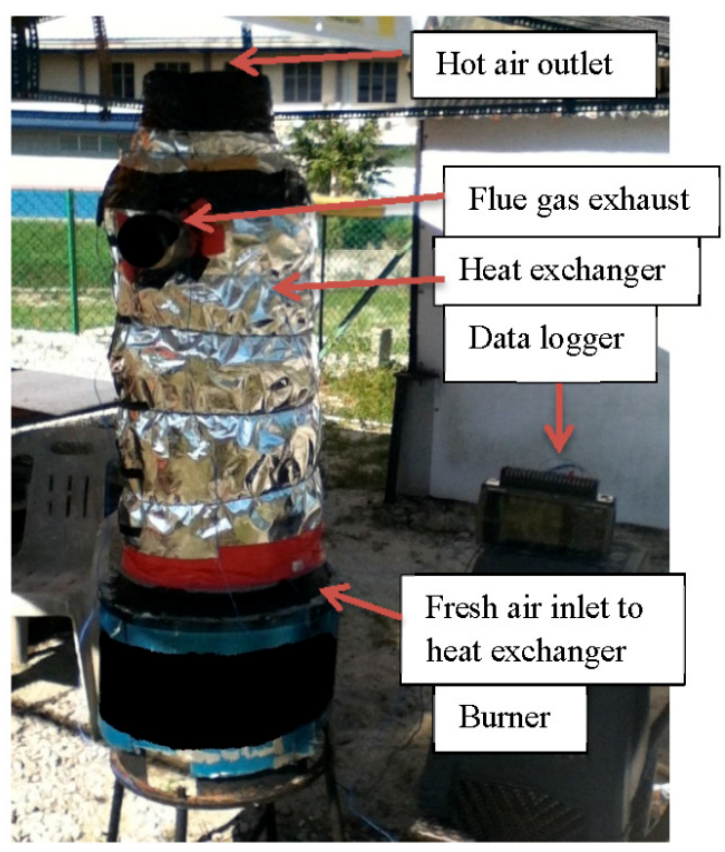

Figure 3: $\quad$ The fabricated model of the TBU.

measure the temperatures of the internal and external walls of the heat exchanger as well as the temperatures of the inlet and outlet air and flu gas. The velocity of hot air was measured using vane probe and anemometer type VT200 with accuracy $\pm 3 \%$. The calorific value of coal is measured by Bomb Calorimeter model C5000. A weight measuring machine was used to measure the weight of the feeding coal with accuracy of $1 \mathrm{~g}$ in a range of $5 \mathrm{~kg}$.

\subsection{Thermal analysis}

Figure 4 shows the variation of the temperature of the wall in the flue gas side $T_{\text {wi }}$, the wall temperature in the air side, $T_{w o}$, the ambient temperature, $T_{a}$ and outlet temperature from the heat exchanger, $T_{a o}$ with the temperature of the flue gas, $T_{f i}$ from the burner to the inlet of the heat-exchanger. At the coal feeding rate, fr to the burner of $0.271 \mathrm{~kg} / \mathrm{hr}$, the temperature range of the hot air out from the heat exchanger was measured to be within the range between $55-71^{\circ} \mathrm{C}$, at inlet flue gas temperature range from $91^{\circ} \mathrm{C}$ to $160^{\circ} \mathrm{C}$. The produced air temperature supplied to the drying chamber is suitable to dry wide range of products; e.g. food, chilly, fish, and herbs. The results show that the hot air temperature was higher than the ambient temperature by $\sim 40^{\circ} \mathrm{C}$, maximum. The minimum outlet flue gas temperature was $91^{\circ} \mathrm{C}$ and the maximum was $160^{\circ} \mathrm{C}$. The wall temperature in the flue gas side was higher than the wall temperature in the air side in the range of 2 to $11^{\circ} \mathrm{C}$. 


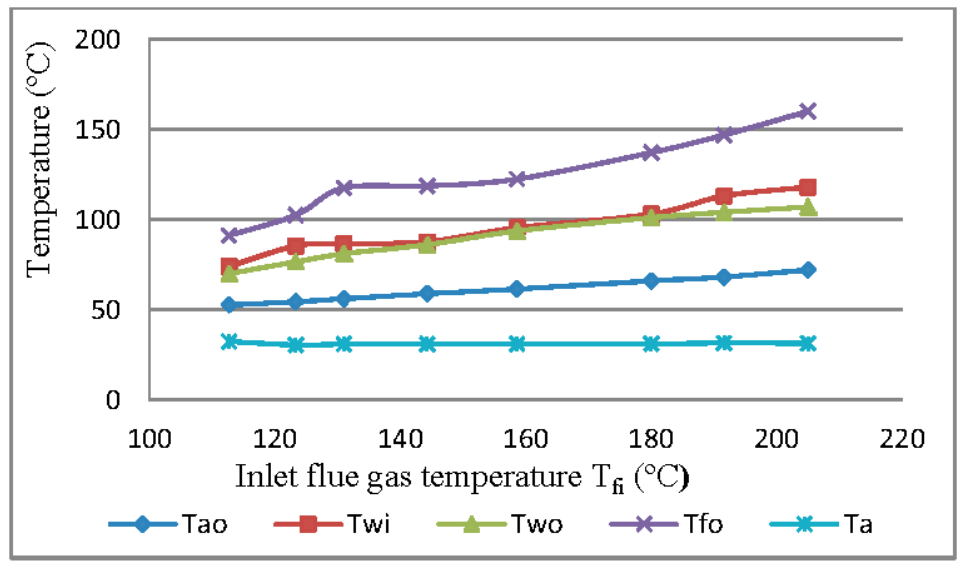

Figure 4: Effect of inlet flue gas temperature on the outlet hot air and wall temperatures.

Figure 5, shows the variation of the hot air exit from the heat exchanger with the time for the burning of the coal at two rates, $f r=0.426$ and $0.271 \mathrm{~kg} / \mathrm{hr}$. The results show that the feeding rate of $0.271 \mathrm{~kg} / \mathrm{hr}$, was more suitable than the feeding rate of $0.426 \mathrm{~kg} / \mathrm{h}$. The feeding rate of $0.271 \mathrm{~kg} / \mathrm{hr}$ was more feasible because the temperature was stable between $\left(55-71^{\circ} \mathrm{C}\right)$ for a long period of burning time and the temperature did not rise above $71^{\circ} \mathrm{C}$ at the full combustion of the coal.

The feeding rate of $0.426 \mathrm{~kg} / \mathrm{hr}$ was inappropriate because the temperature rose above $100{ }^{\circ} \mathrm{C}$ at the full combustion of the coal, which is not suitable for drying. At the feeding rate of $0.426 \mathrm{~kg} / \mathrm{hr}$, the temperature of the hot air was

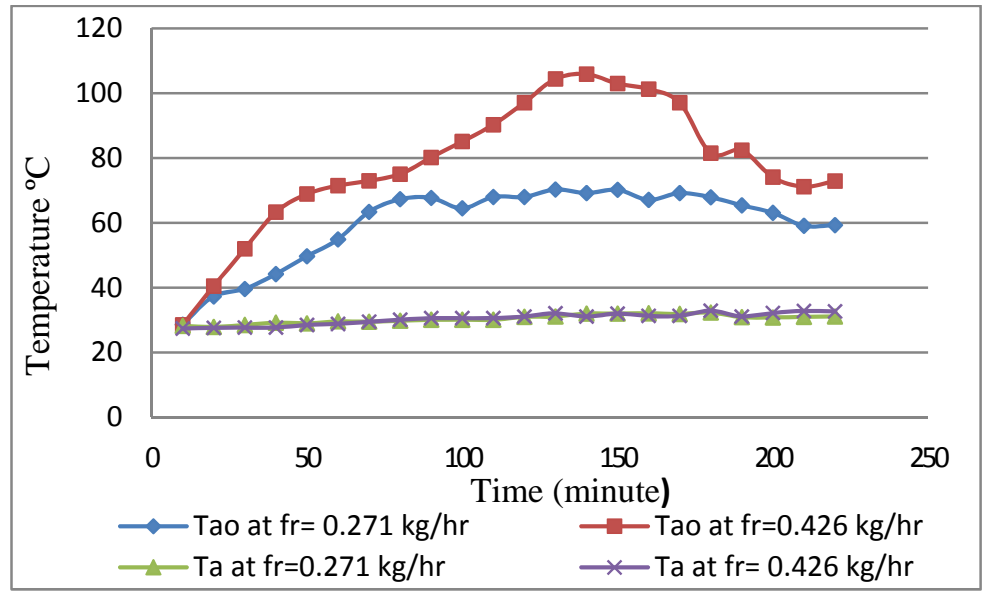

Figure 5: $\quad$ Effect of feeding rate on the stability of drying air temperature. 
higher than the ambient temperature by $60^{\circ} \mathrm{C}$ maximum. At the feeding rate of $0.271 \mathrm{~kg} / \mathrm{hr}$, the temperature of the hot air was higher than the ambient temperature by about $40^{\circ} \mathrm{C}$ maximum. It can be deduced that the decrease in the feeding rate of the coal leads to a stable hot air temperature for long time of burning, which is important for performing good drying process.

\subsection{Validation of the mathematical procedure}

To validate the mathematical procedure which was adopted for the TBU design, a comparison has been carried out between the results of the design and the results of the experimental measurements as shown in table 2 .

\subsection{System efficiency}

The efficiency of TBU can be defined as the ratio of useful heat transferred to air to the energy potential of fuel. It can calculate by use the equation as below:

where

$$
\eta=\frac{Q_{u}}{Q_{f}}
$$

$$
\begin{gathered}
Q_{u}=\dot{m}_{a} C p\left(T_{a o}-T_{a}\right) \\
Q_{f}=C_{v} m_{f}
\end{gathered}
$$

where

$Q_{u}$ : useful energy transferred to air,

$Q_{f}$ : energy potential of fuel,

$C_{v}$ : calorific value of a fuel,

$m_{f}$ : mass of fuel used to burn.

Table 2: $\quad$ Validation of the results.

\begin{tabular}{lllll}
\hline No. & Item & Design calculation & Experimental result & Error (\%) \\
\hline 1 & $\mathrm{~T}_{\mathrm{wi}}$ & 120 & 118 & 1.66 \\
2 & $\mathrm{~T}_{\mathrm{wo}}$ & 120 & 107 & 10.8 \\
3 & $\mathrm{~T}_{\mathrm{fi}}$ & 190 & 205 & 7.3 \\
4 & $\mathrm{~T}_{\mathrm{fo}}$ & 170 & 160 & 5.8 \\
5 & $\mathrm{~T}_{\mathrm{ao}}$ & 80 & 72 & 10 \\
5 & $\mathrm{~h}_{\mathrm{f}}$ & 6.74 & 6.855 & 1.6 \\
6 & $\mathrm{~h}_{\mathrm{a}}$ & 6.9 & 6.39 & 7.3 \\
\hline
\end{tabular}

The calorific value of the coal was measured experimentally using bump calorimeter and it was found equal to $25918 \mathrm{~J} / \mathrm{g}$. At feeding rate of $0.271 \mathrm{~kg} / \mathrm{hr}$, the efficiency of the tested TBU was found to be $21.5 \%$ when the measured supply drying air temperature $54.1^{\circ} \mathrm{C}$. The efficiency increases to $39.8 \%$ when the supplied hot air temperature was $68^{\circ} \mathrm{C}$. Bena and Fuller [5] reported the 
overall efficiency of their TBU system within 5 hours of burning wood and it was about $27 \%$.

\section{Conclusions}

The procedure adopted in the present work to design, construct and test a thermal back up unit for hybrid drying demonstrated the following conclusions:

- At charcoal fuel feeding rate of $0.426 \mathrm{~kg} / \mathrm{hr}$, the temperature of the hot air is higher than the ambient temperature by about $60^{\circ} \mathrm{C}$.

- Reduction in the feeding rate to $0.271 \mathrm{~kg} / \mathrm{hr}$ resulted in the temperature of the hot air to be higher than the ambient temperature by about $40^{\circ} \mathrm{C}$.

- At feeding rate $0.271 \mathrm{~kg} / \mathrm{hr}$, the efficiency of thermal back-up system $21.5 \%$ and 39.8 when the hot air temperature 54.1 and $68^{\circ} \mathrm{C}$ respectively.

- The decrease in the feeding rate of the coal leads to the stable hot air temperature for long drying time, up to overnight.

- The TBU is feasible for providing hot air suitable for drying any type of material by controlling the amount of the feeding rate.

\section{Acknowledgements}

The authors acknowledge the Ministry of Higher Education (MOHE) Malaysia, for providing the financial fund under PRGS research grant. The main author acknowledges Universiti Teknologi PETRONAS for supporting his PhD study under the Tuition Fees Assistance (TFA) scheme.

\section{References}

[1] Jaishree Prasad and V.K. Vijay, Experimental studies on drying of Zingiber officinale, Curcuma longa 1 . and Tinospora cordifolia in solar-biomass hybrid drier, Renewable Energy, 30, pp. 2097-2109, 2005.

[2] A. Madhlopa and G. Ngwalo, Solar dryer with thermal storage and biomass-backup heater, Solar Energy, 81, pp. 449-462, 2007.

[3] E. Tarigan and P. Tekasakul, A mixed-mode natural convection solar dryer with biomass burner and heat storage back-up heater, ANZSES 2005.

[4] T. Thanaraj, D.A.N. Dharmasena and U. Samarajeewa, development of a rotary solar hybrid dryer for small scale copra processing, Tropical Agriculture Research, 16, pp. 305-315, 2004.

[5] B. Bena and R.J. Fuller, Natural convection solar dryer with biomass backup heater, Solar Energy, vol. 72, pp. 72-83, 2002.

[6] Ayensu, A., Dehydration of food crops using a solar dryer with convective heat flow, Solar Energy, 59, pp. 121-126, 1997.

[7] J. P. Holman, Heat Transfer, Eighth SI Metric Edition, McGraw-Hill, New York, 2001. 
[8] W. H. McAdams, Heat Transmission, 3d ed., McGraw-Hill Book Company, New York, 1954.

[9] Y. M. Yunus, H. H. Al-Kayiem and K. A. K. Albaharin, Design of a Biomass Burner Gas-to-Gas Heat Exchanger for Thermal Backup of a Solar Dryer, Journal of Applied Science 11 (11): pp. 1929-1936, 2011.

[10] Hussain H. Al-Kayiem and Yusheila Md Yunus, Drying of EFB by Hybrid Solar/Biomass Thermal Backup, International Conference on Mechanical Engineering Research (ICMER2013), Bukit Gambang Resort City, Kuantan, Pahang, Malaysia, 2013. 